\title{
Sodium Concentration in Potable Ground Water in Coastal Belt of Bangladesh Due To the Effect of Global Warming: A Potential Health Risk
}

\author{
A. M. Tuhin-ul Alam ${ }^{1}$, M. Kutub U Khan ${ }^{2}$ \\ Dept. of civil engineering, Military institute of science and technology (MIST). DHAKA-1216 BANGLADESH
}

\begin{abstract}
The sea level rise due to global warming is a major environmental issue. It is a burning concern for the countries having coastal belt around the world and Bangladesh would be one of the most affected country. Taking the above facts into concern, our thesis study was undertaken particularly to find out the relation of sodium content with distance from the sea, depth of tube well, seasonal variation and daily dietary sodium intake safe limit. The study was based on two inland sites (Nawabganj and Faridpur) and two coastal sites (Laxmipur and Patiya). Deliberate study of the Tube well sampling of Patiya and Laxmipur at varying depth found that salt intrusion increases with the increase in depth. In Patiya, all tube wells were deep tube wells since the potable aquifer is found below $600 \mathrm{ft}$. This phenomenon confirms the salt water intrusion is higher through deeper aquifer in Paitya. We assessed that due to ground water recharge from both deep percolation and increase in contributing stream flow from Karnafully River in Chittagong district, the salinity intrusion is lowered in monsoon. Our Analysis of the BGS database of sodium in well water shows that for the inland district Nawabganj and Faridpur, the sodium concentration within the W.H.O. recommended limit of $25 \mathrm{mg} / \mathrm{L}$. American Water Works Association (AWWA) reports that normally the dietary intake of sodium from fresh water is limited to 3 to 5\% (U.S. Environmental Protection Agency, 2003; American Water Works Association, 1999), and the potential sodium daily intake from the waters of Nawabganj and Faridpur were found in line to that reported by AWWA. Our sampling study and analysis of tube wells and ponds in Patiya Upazilla which is nearer to coast had much higher concentration of sodium than the W.H.O. recommended limit. This is putting the mass people of Patiya Upazilla and the surrounding zone in risk of cardiovascular diseases and also in risk of developing hypertension.
\end{abstract}

Key Words: costal Bangladesh, drinking water, global warming, hypertension, sodium content.

\section{Introduction}

Climate change is an important issue nowadays. Various natural phenomenon and human activities are making the world warm to warmer. The ultimate result is global warming, i.e. climate change. Rising temperature in the atmosphere causes sea level rise and affects low lying coastal areas and deltas of the world. In 1990, an Intergovernmental Panel on Climate Change estimated that with a business-as-usual scenario of greenhouse gas emission, the world would be $3.3^{0} \mathrm{C}$ warmer by the end of the next century, with a range of uncertainty of $2.2^{\circ} \mathrm{C}$ to $4.9^{\circ} \mathrm{C}$ (Warrick et al., 1993). With rise in temperature, sea level will rise because of thermal expansion and ice melt of polar cap. Among the countries to be affected by the sea level rise, Bangladesh would be the worst sufferer as found out in numerous researches.

Sea level rise would have various impacts on Bangladesh, a coastal country facing $710 \mathrm{~km}$ long coast to the Bay of Bengal. It already has affected Bangladesh by land erosion, salinity intrusion, flood, damage to infrastructures, crop failure, fisheries destruction, and loss in biodiversity. In worst case scenario, One-meter sea level rise (SLR) will affect the country's vast coastal area and flood plain zone which will be flooded with sea water. It will affect Millennium Development Goals, causing environmental refugees. Most vulnerable sectors to one meter sea level rise are habitation in coastal area, coastal resources, water resources, agriculture and the ecosystem of Bangladesh.

The concern for environment engineers and health personal is that in costal Bangladesh the contribution of daily salt intake from drinking water is significant enough to be of concern and be deemed a public health and environmental crisis. It is important to note that a significant population of Bangladesh lives in the coastal areas. The potable water in the coastal area is under the influences of sea water and progressively due to bad water management practices sea water intrusion into the costal aquifers are of a concern.

We looked at the sodium content of well waters from four distinct geological regions of Bangladesh and evaluated for potential sodium contribution to the daily sodium intake and daily sodium intake limit set by the World Health Organization and the US Environmental Protection Agency. The surface water and well water database was from Patiya and Laxmipur at the coast in Chittagong district where the groundwater would be prone to estuarine salt water intrusion and inland regions of Nawabganj in Rajsahi District, and Faridpur in 
Dhaka district where the ground water are not influenced by sea water intrusions due the distance from coast. Interpretation of the data on the conductivity, sodium content, saline content, TDS content of the Sampling sites indicated and conformed to Geological and environmental facts that remarkable saline intrusion is occurring which also have relation with distance from coast, Depth and Seasonal variation.

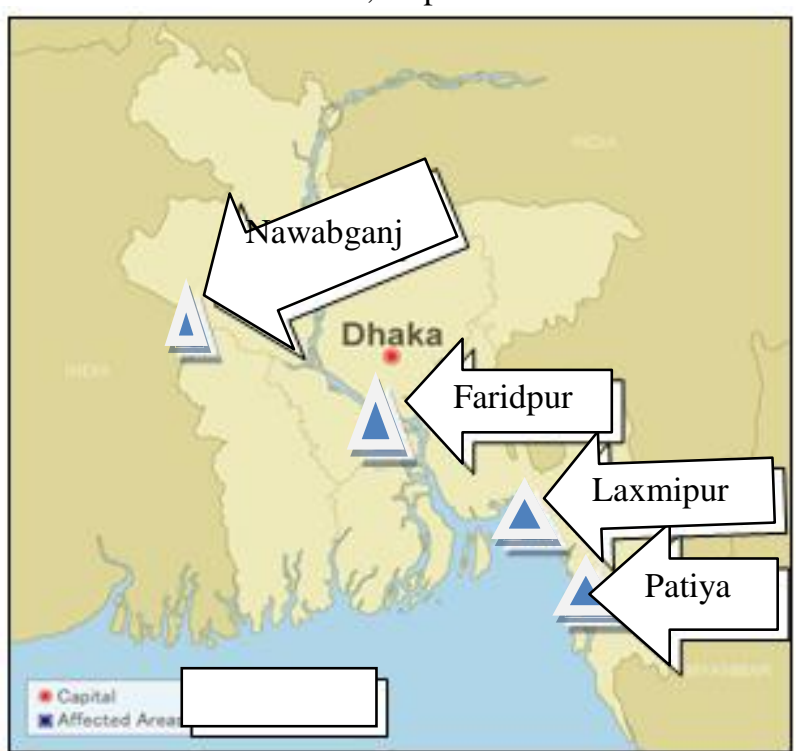

Map of Bangladesh showing the regions where the well waters were sampled

\section{Approach And Methodology}

Water samples were collected from ponds and tube well at various depths of 27 scattered locations at Upazilla Patiya in Chittagong District in summer and rainy season. Standard sampling procedures have been followed for collection, transport, preserve and investigate. Laboratory tests for Conductivity, Salt and Total Dissolved Solids (TDS) were carried out in the Environmental Engineering Laboratory of Military Institute of Science and Technology (MIST). Laboratory analysis of Sodium content and salt content (further confirmation) was done in the Pathology Lab of National Heart Foundation and Research Institute of Dhaka. All these data were analyzed and graphical correlation was carried out based on following five factors:

1. Correlation between surface and sub-surface sampling points

2. Depth of Sampling point for sub surface

3. Distance of sampling points from the coast.

4. Seasonal variation.

5. Standard daily salt intake safe limit.

Field samples were collected from 15 scattered tube wells at different depth and 12 ponds in two different seasons - summer and rainy season. The tube wells were having average depth varying between 600 feet and 1100 feet. Standard sampling procedure has been followed in collection, transportation; preservation and also GPS Coordinates (Grid Reference) of all sampling points were collected. The locations of the sampling sites are shown as per grid reference in the below map:

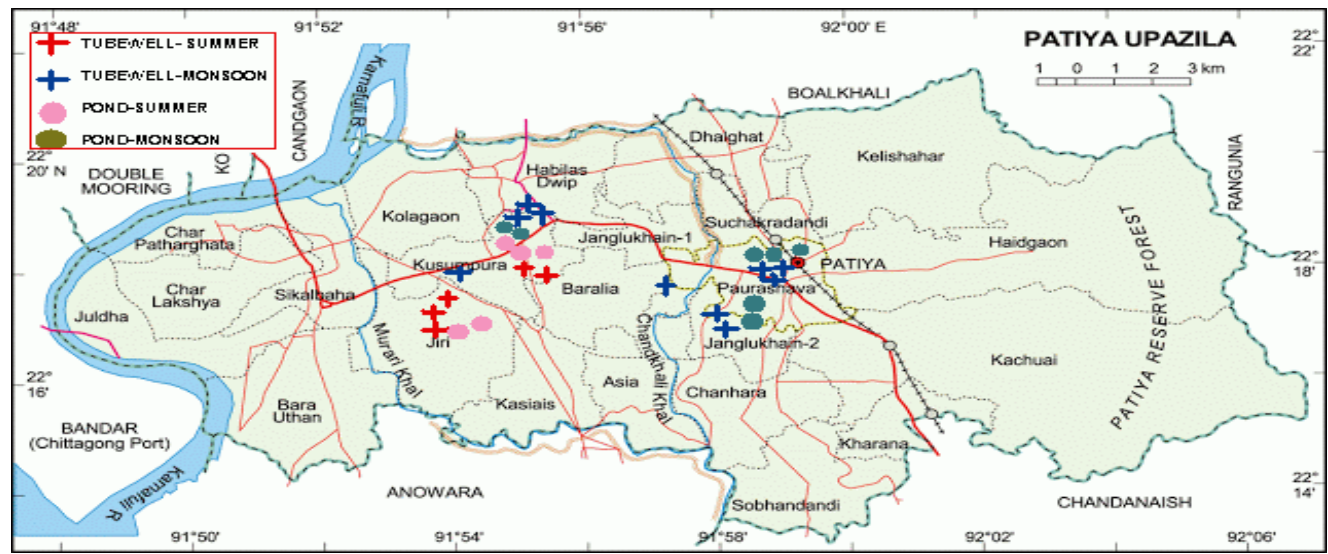

Fig 1: Map of Patiya Upazila showing the regions with side grid reference where the 
Well and pond waters were sampled

The collection of the sample water from the tube well was done following standard procedures. Fresh $250 \mathrm{ml}$ mineral water bottle were used to collect the sample. Before collecting, the bottles were emptied and dried. The handle of tube well were pressed $100+/-(5)$ times before filling the bottle to ensure that the sample is perfectly from the desired depth. To make it more accurate, all the samples were collected after the peak use at noon. The samples from the ponds were collected in the morning to allow undisturbed and sediment free water. The bottles were filled up completely to avoid any air contact and oxidation. After that the bottles were packed in dark box and transported to the laboratory for analysis.
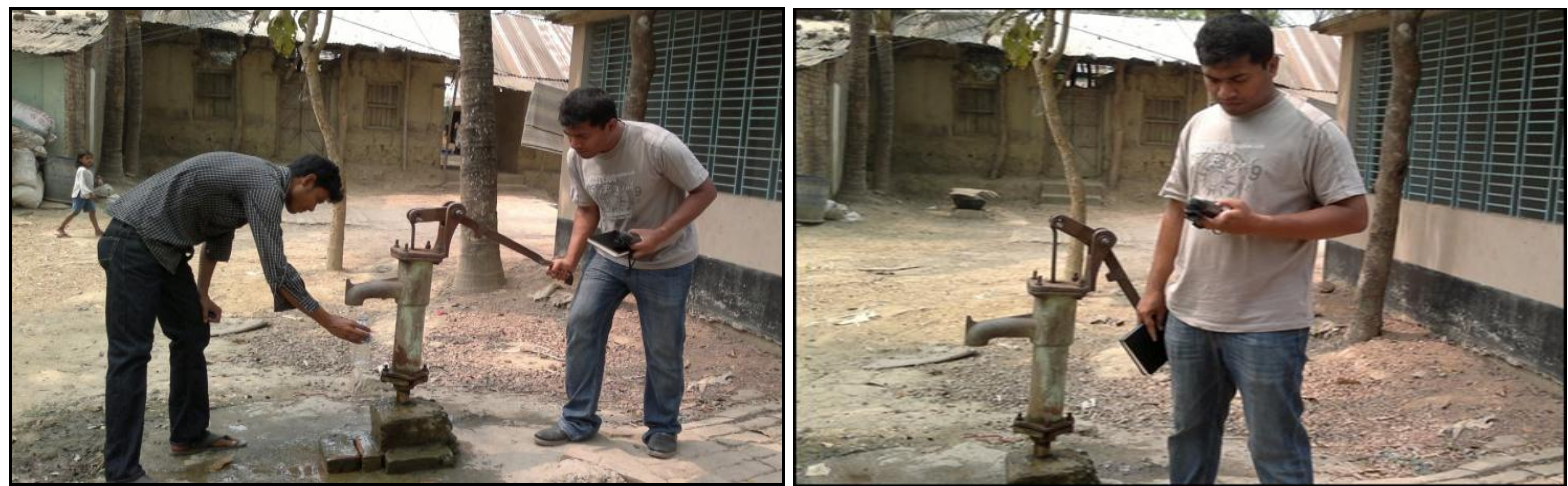

Fig 2: Collection of Sample water from the tube wells in Patiya Upazila

The samples were collected in two different phases. At first it was collected during summer season in the month of April 2013 and then during rainy season in the month of July 2013. In both cases, the sampling record was done carefully and kept the record separately to compare the data of these two groups. Laboratory analysis was done in two phases. In first phase we used the Environmental Engineering Laboratory of MIST for the Conductivity test, Salt Test and Total Dissolved Solid (TDS) test. In second ph. we used the Pathology Laboratory of National Heart Foundation, Dhaka for measuring Sodium content.
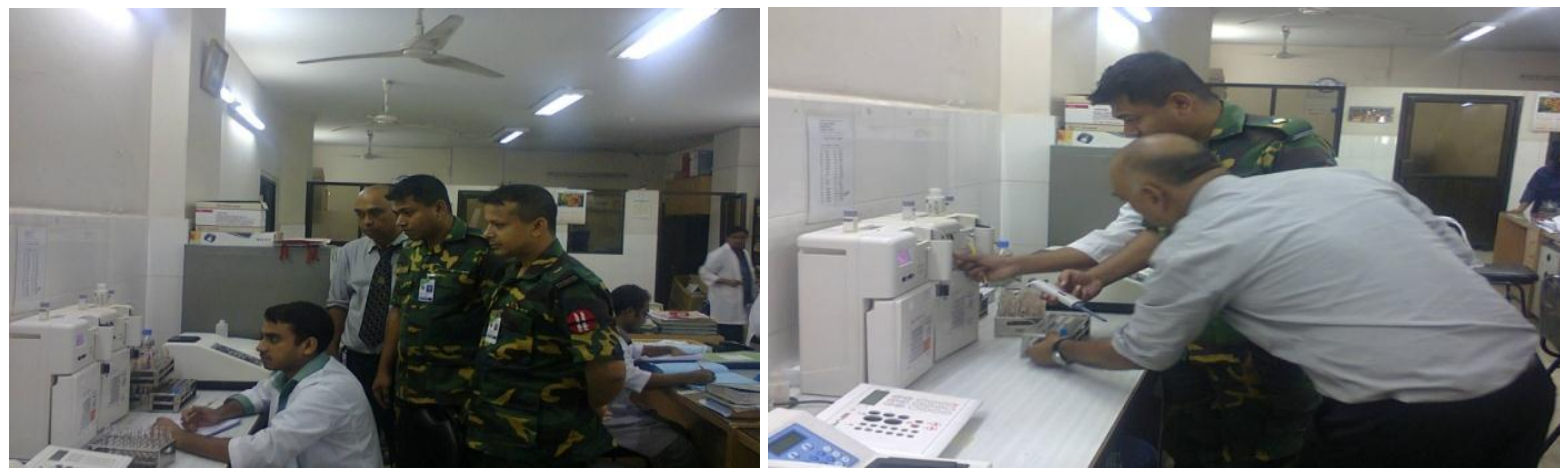

Fig 3. Sodium Content Measurement being done in Pathology Laboratory of National Heart Foundation, Dhaka

We have conducted mass balance and trend analysis on the existing British Geological Survey (BGS) data base (BGS, 2001) on sodium content for three locations- Laxmipur, Faridpur and Nawabganj and for sampled well waters and pond water from Patiya as well. The survey data base reported the sodium content well water samples with exact geological coordinates of the wells along with the depth of the sampled wells. For all four locations, we looked at the distribution of sodium levels in the sampled wells using Excel Spreadsheet. We also calculated using Excel spreadsheet the potential relative dietary contribution of sodium from drinking water. Further we correlated the sodium content of the wells sampled to the reported well depth. Finally, we evaluated all correlated data graphically. All statistical analysis of the data base was calculated using Excel spreadsheet and reported as median and mean \pm standard deviation.

\section{Results And Discussion}

Results and discussion according to distance From Coast In our thesis study, among the four study sites, Nawabganj and Faridpur are inland and Laxmipur and Patiya are in coastal region. We have found that generally the sodium concentration is increasing nearer to the coast of Bay of Bengal which is shown below: 
Sodium Concentration in Potable Ground Water in Coastal Belt of Bangladesh Due To the Effect .....

\begin{tabular}{|c|c|c|c|c|c|c|}
\hline Ser & Location & $\begin{array}{l}\text { Average } \\
\text { elevation }\end{array}$ & $\begin{array}{l}\text { Distance from } \\
\text { Coast (approx.) }\end{array}$ & $\begin{array}{l}\text { Limit of } \\
\text { Concentration }(\mathrm{mg} / \mathrm{L})\end{array}$ & $\begin{array}{l}\text { Median/ Average } \\
\text { Concentration }\end{array}$ & Reference Graph \\
\hline 2 & Faridpur & $\begin{array}{l}15 \text { meters (49 } \\
\text { feet) }\end{array}$ & $220 \mathrm{~km}$ & $36.4 \pm 39.6$ & $36(\mathrm{mg} / \mathrm{L})$ & Figure 4.1(b) \\
\hline 3 & Laxmipur & $\begin{array}{l}11 \text { meters }(36 \\
\text { feet) }\end{array}$ & $100 \mathrm{~km}$ & $46.84 \pm 120.97$ & $68(\mathrm{mg} / \mathrm{L})$ & Figure 4.2 (a) \\
\hline 5 & $\begin{array}{l}\text { Patiya: } \\
\text { Monsoon }\end{array}$ & $\begin{array}{l}7 \text { meters }(23 \\
\text { feet) }\end{array}$ & $16 \mathrm{~km}$ & $22.9 \pm 48.09$ & $\begin{array}{l}35.495(\mathrm{mg} / \mathrm{L}) 35 \\
(\mathrm{mg} / \mathrm{L}) \text { Avg }\end{array}$ & Figure 4.2 (c) \\
\hline
\end{tabular}

Table: Sodium Concentration according to distance from coast

(a)

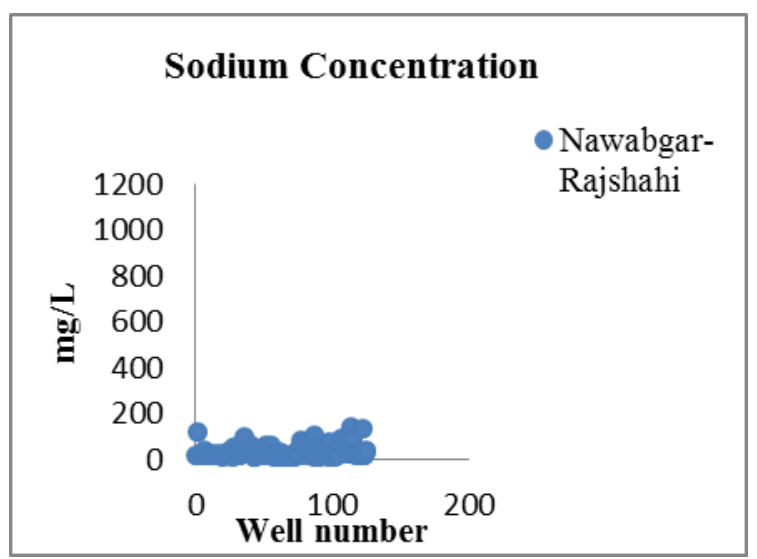

(b)

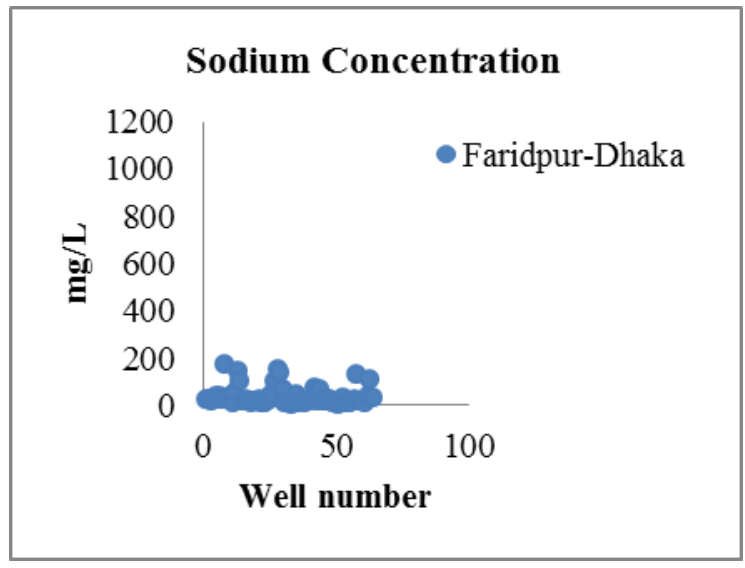

Fig 4.1: Graph of sodium concentration against well for different wells for the regions of (a) Nawabganj and (b) Faridpur

(a)

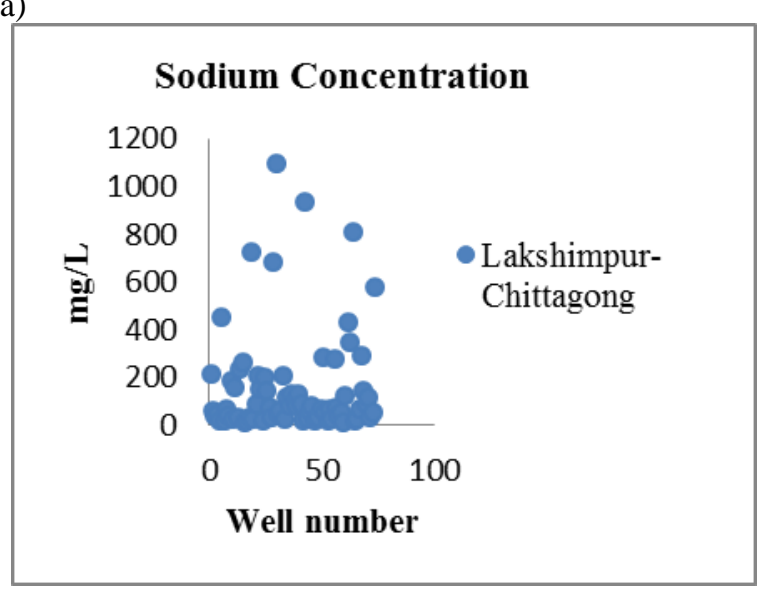

(b)

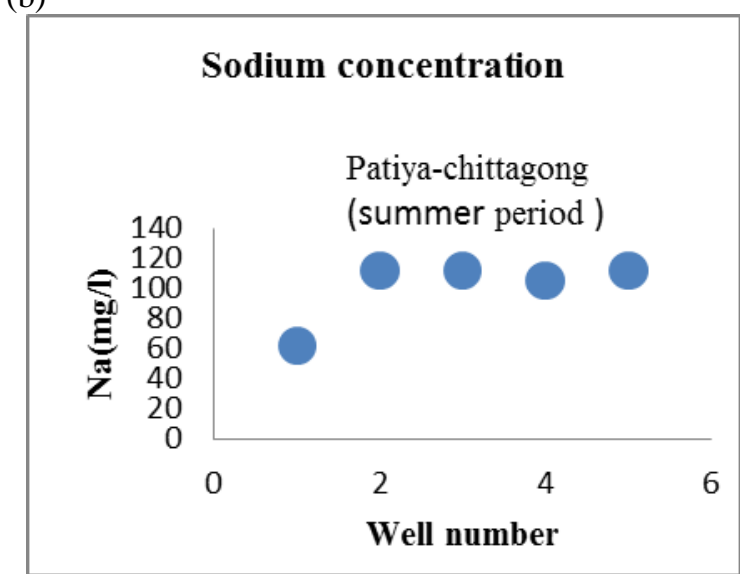

Fig 4.2: Graph of sodium concentration against well for different wells for the regions of (a) Laxmipur and (b) Patiya-Summer Period

(c) 


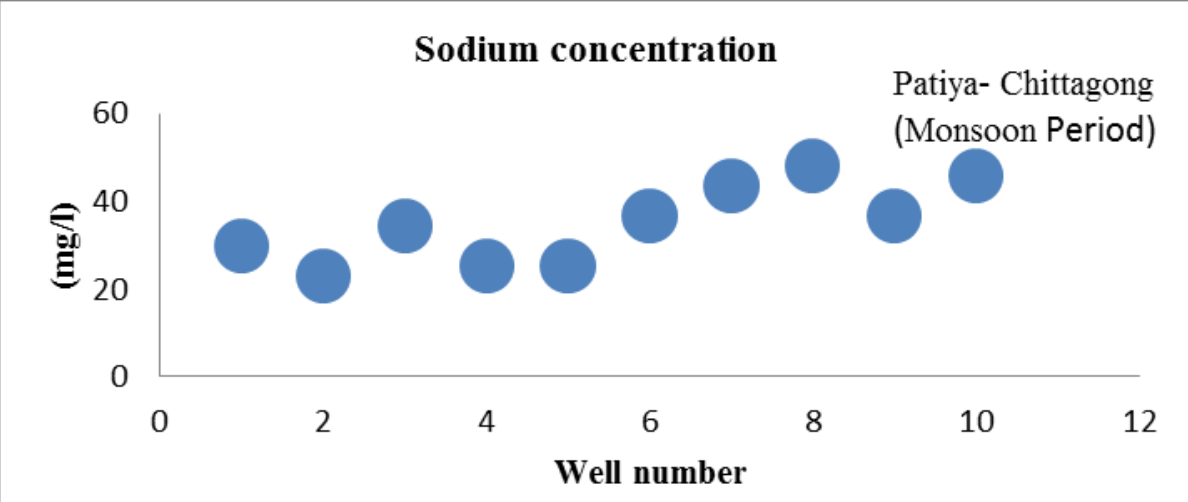

Fig 4.2: Graph of sodium concentration against well for different wells for the regions of (c) Patiya-Monsoon Period

These explain the fact that salt water intrusion through the ground water flow is higher in coastal region and it proportionally decreases with distance from the coast.

Results and discussion according to Depth test results for Sodium concentration of water sample from Patiya and Laxmipur are graphically shown in figure 4.3 and figure 4.4 (a) and (b). In Laxmipur, (Figure 4.3) in surface water sample for depth between 0 to $20 \mathrm{ft}$. the sodium concentration is generally varying from $10 \mathrm{mg}$ to $280 \mathrm{mg} / \mathrm{L}$ (discarding the isolated data). The contributing factors may include stagnant water, fertilizer and pesticide pollution by overland flow and bathing, washing and use of detergent, etc. The tube wells depths are generally varying from $180 \mathrm{ft}$ to $300 \mathrm{ft}$. where the sodium concentrations are generally varying between 20 to 90 $\mathrm{mg} / \mathrm{L}$. These concentrations are gradually increasing with depth.

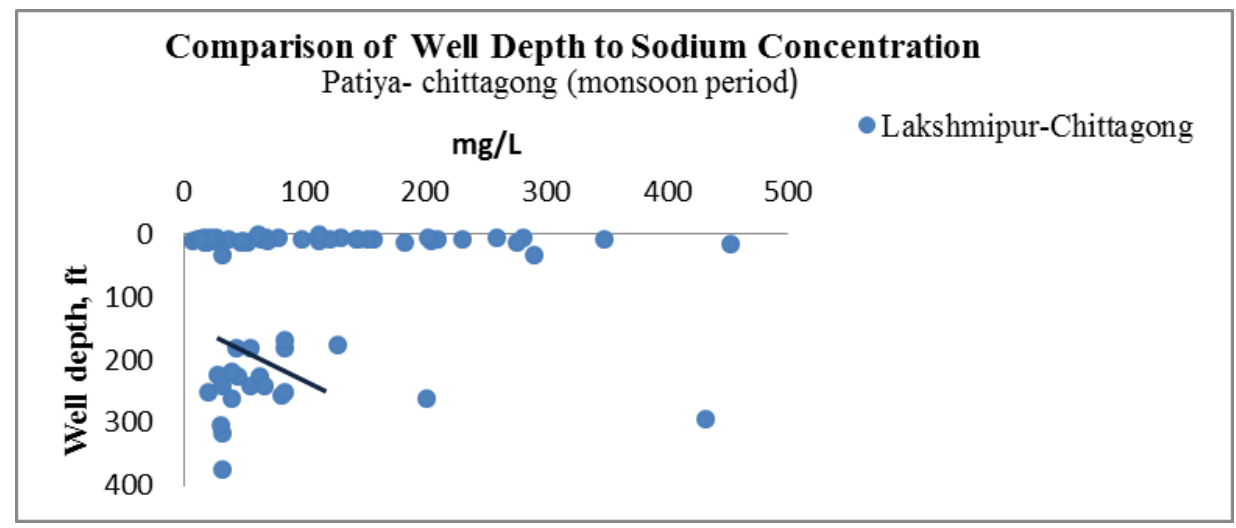

Fig 4.3: Graph of sodium concentration against well depth for different wells for the region of Laxmipur

This fact was farther confirmed in the test results of water samples from Patiya in both summer and monsoon season, which is shown below in figure 4.4 (a) and 4.4 (b). In both figures, the trend lines are clearly indicating that sodium concentration is increasing considerably with depth.
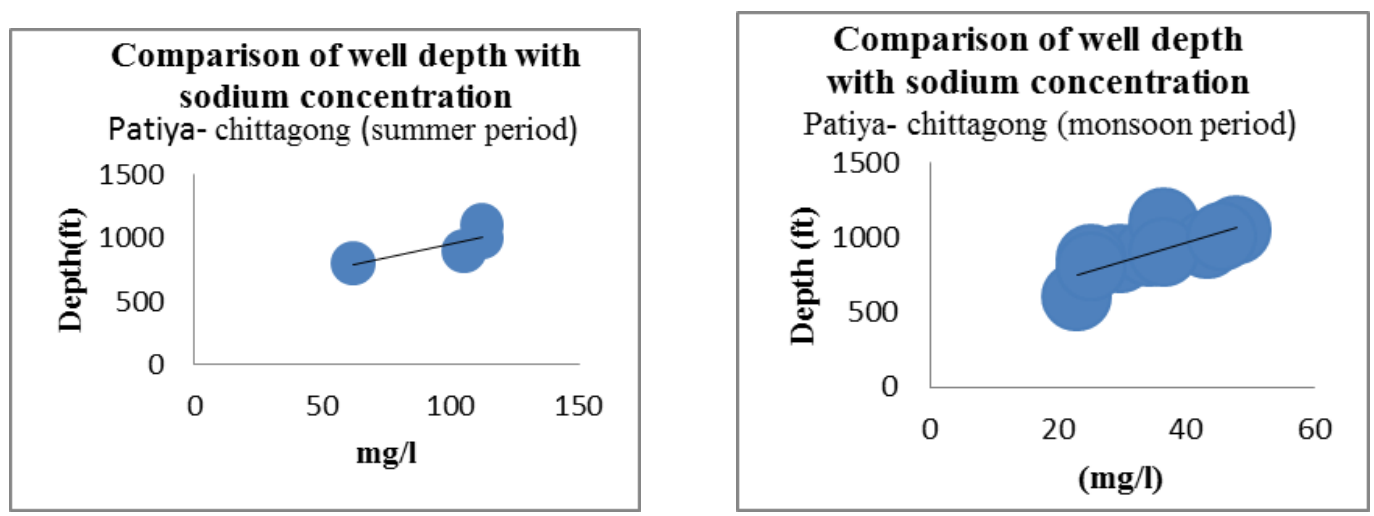

Fig 4.4: Graph of sodium concentration against well depth for different wells for the region of Patiya in summer and Monsoon Period 
These is rather an important fact to take into consideration since mass people's belief is that deeper wells have fresher potable water. But this findng indicate that salt intrusion is higher in deeper aquifer near the sea. Its important to note that in Patiya, all tube wells are deep tube wells since the potable aquifer is found below $600 \mathrm{ft}$. These phenomena confirms the salt water intrusion through deeper aquifer in Patya. The reason may lie in the lowering of water table by execesssive withdrawl of well water by pumping and theirby reversing the pressure gradient between the seawater level and ground water level. Also the reduction of recharging the potable water aquifer and ground water flow towards sea by the decrese in contributing stream flow may be another reason. It is important to note that this findings rather explains that with the sea level rise due to global warming, the hydraulic pressure gradient between seawater level and ground water table increases. Thereby, the rate of salinity intrusion in the coastal region is incraesing proportionaly with the sea level rise.

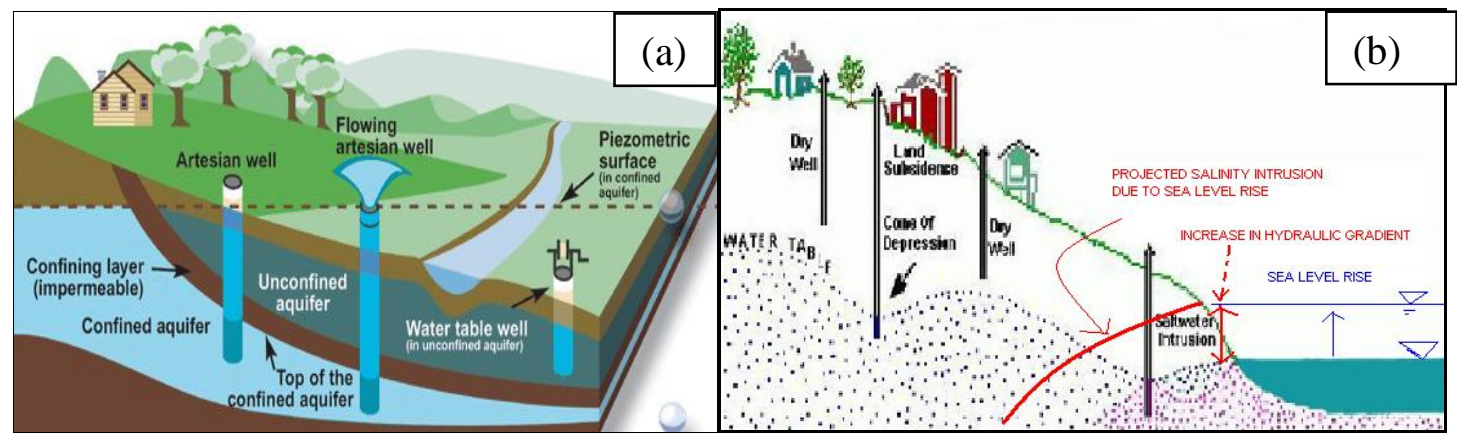

Fig 4.5(a) \&(b): Salt water intrusion in deeper aquifer near sea (Source: U.S. Geological Survey/College of Alameda Physical Geography)

Results and discussion according to seasonal variation according the graphical presentation of sodium concentration of tube well samples from Patya Upazilla shown in figure 4.6 (a) and (b), it is clearly visible that the salt concentration is higher during summer season and consideraby lower in monsoon. The sodium concentration during summer season varied from $61.83 \mathrm{mg} / \mathrm{L}$ to $112.3 \mathrm{mg} / \mathrm{L}$, whose average is $100 \mathrm{mg} / \mathrm{L}$ and median is $112.2 \mathrm{mg} / \mathrm{L}$. The sodium concentration during monsoon varied from $22.9 \mathrm{mg} / \mathrm{L}$ to $48.09 \mathrm{mg} / \mathrm{L}$, whose average is $35 \mathrm{mg} / \mathrm{L}$ and median is $35.495 \mathrm{mg} / \mathrm{L}$. It clearly indicates that, due to ground water recharge from both deep percolation and increase in contributing stream flow from Karnafully river in Chittagong district. This fact can be further supprted by the water salinity map of Bangladesh by SRDI given below in figure 4.7. where it is clearly seen that fresh water flow in estuarian tributaries is reducing the salt water intrusion in Barisal/Bhola area

(a)

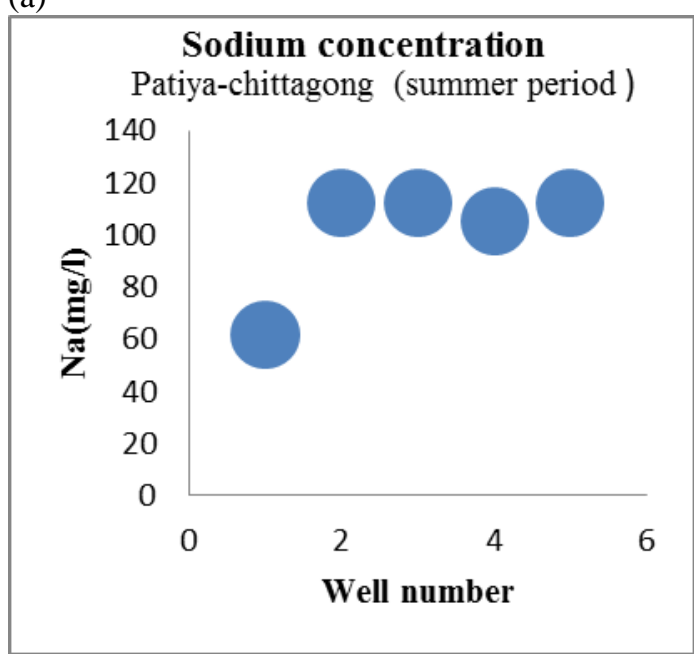

(b)

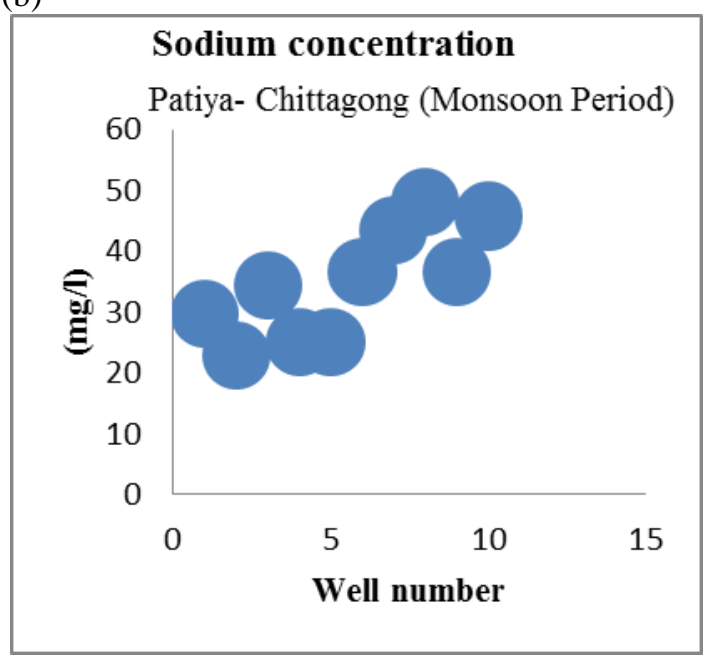

Fig 4.6: Graph of sodium concentration against different wells for the region of Patiya (a) Summer Period (b) Monsoon Period 


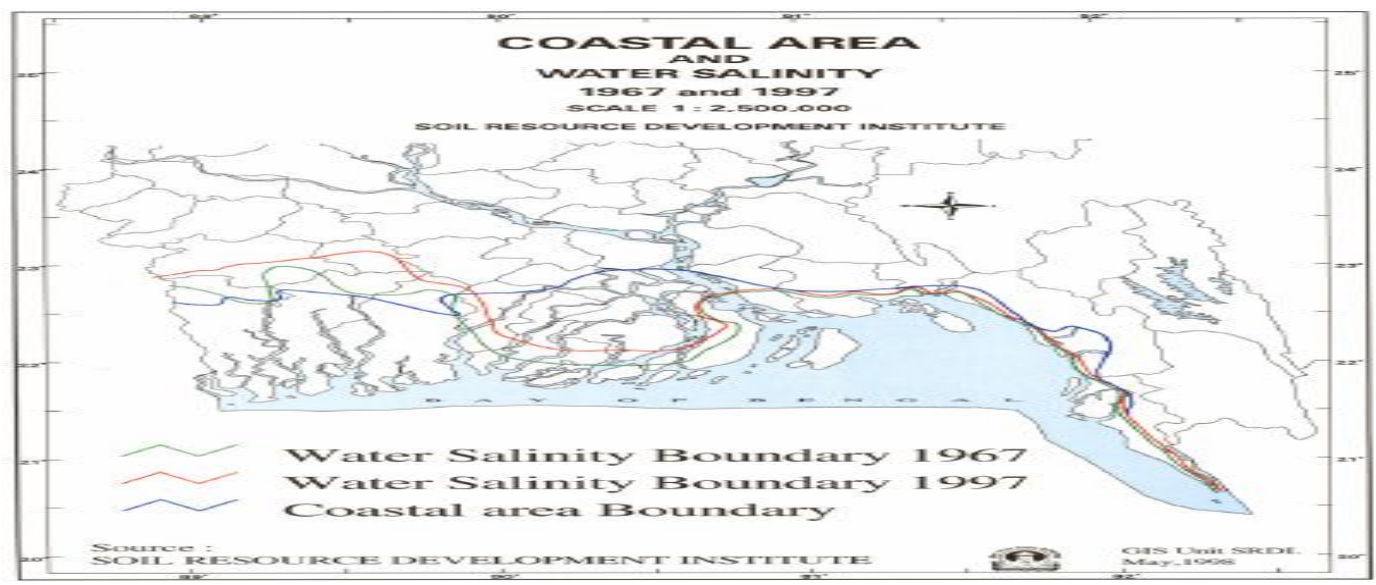

Fig 4.7: Water salinity map of Bangladesh (Source: SRDI, 1998a)

On the other hand, the sodium concentration in Pond water (Figure 4.8) during summer varied from $38.9 \mathrm{mg} / \mathrm{L}$ to $59.5 \mathrm{mg} / \mathrm{L}$ whose average is $48 \mathrm{mg} / \mathrm{L}$. During monsoon the concentration varied from $16.03 \mathrm{mg} / \mathrm{L}$ to 57.25 $\mathrm{mg} / \mathrm{L}$ whose average is $40 \mathrm{mg} / \mathrm{L}$. The concentration is still higher than the standard $25 \mathrm{mg} / \mathrm{L}$ (according to WHO guideline) which have negligible change from summer to monsoon. The reasons may include stagnant water, fertilizer and pesticide pollution by overland flow and bathing, washing and use of detergent, etc.

(a)

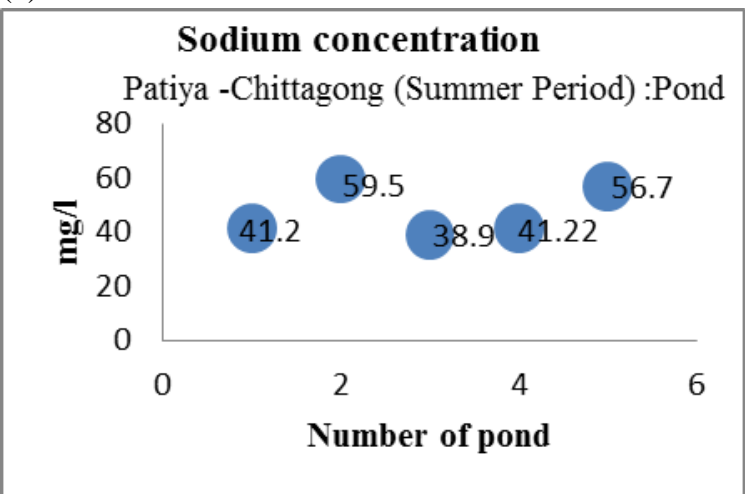

(b)

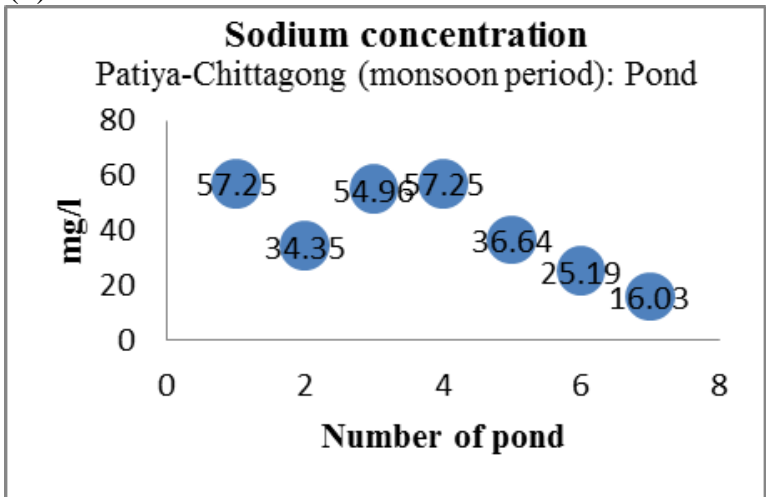

Fig 4.8: Graph of sodium concentration against different Ponds for the region of Patiya in (a) Summer Period and (b) Monsoon Period

Results and discussion according dietary intake and health concern literature reports that normally the intake of sodium from drinking water is limited to around three percent of the total daily dietary intake of sodium. Although, the World Health Organization (W.H.O) does not have a set limit for sodium in drinking water, they do recommend that the concentration of sodium in drinking water should not exceed $25 \mathrm{mg} / \mathrm{L}$. In case sodium concentration in potable water exceeds $25 \mathrm{mg} / \mathrm{L}$, W.H.O. recommends that a health advisory be given by municipalities and this is more applicable for infants, people over 50 years of age and people with hypertension and cardiovascular disease and that the maximum daily dietary intake of sodium be limited to 1500 mg/day (U.S. Environmental Protection Agency, 2003; American Water Works Association, 1999)

Analysis of the BGS database of sodium in well water shows that for the inland district Nawabganj and Faridpur, the well waters' sodium concentration do comply with the W.H.O. recommended limit of $25 \mathrm{mg} / \mathrm{L}$ (refer to Table 4.1 and Figure 4.1a and 4.1b), the median concentrations being 20 and $36 \mathrm{mg} / \mathrm{L}$ for Nawabganj

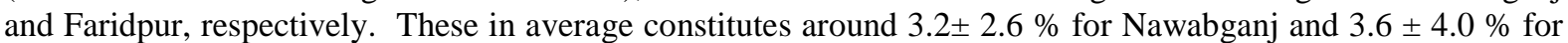
Faridpur of the recommended maximum daily dietary intake of sodium based on five liters of daily water consumption from drinking and cooking water for the wells sampled in Nawabganj and Faridpur (refer to Figure 4.9a and 4.9b). American Water Works Association (AWWA) reports that normally the dietary intake of sodium from fresh water is limited to 3 to 5\% (U.S. Environmental Protection Agency, 2003; American Water Works Association, 1999), and the potential sodium daily intake from the waters of Nawabganj and Faridpur are in line to that reported by AWWA. 
(a)

\section{Potential sodium consumption from \\ drinking water to aha recomended maximum daily sodium intake}

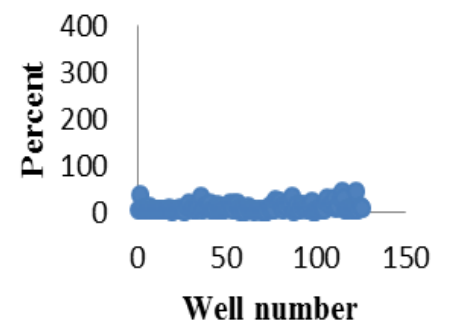

- NawabgarRajshahi (b)

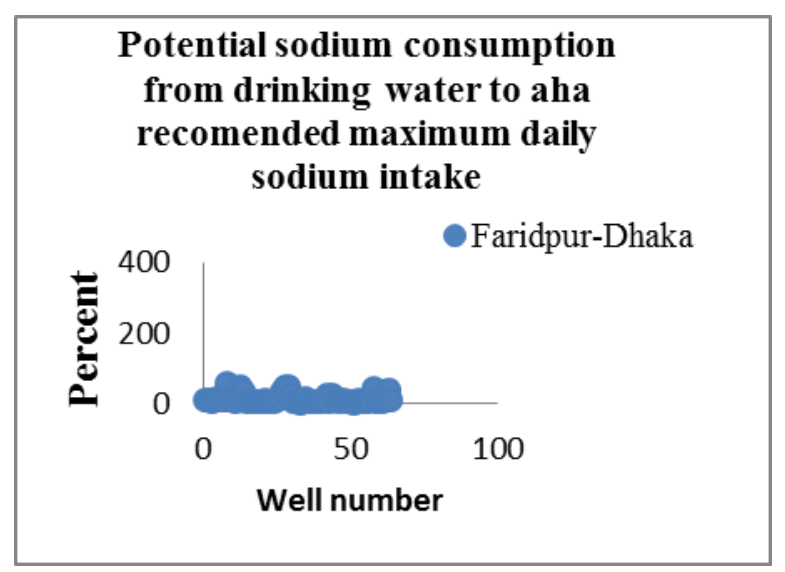

Fig 4.9: Graph of potential daily consumption of sodium from drinking water expressed as a percentage of the recommended maximum upper limit of daily sodium consumption of $1500 \mathrm{mg} /$ day for (a) Nawabganj, and (b)

Faridpur.

On the contrary, the well waters analyzed from the coastal region of Laxmipur had higher concentration of sodium. The wells data in Laxmipur had a median sodium concentration of $68.6 \mathrm{mg} / \mathrm{L}(\mathrm{n}=74)$ (refer to Table 4.1 and Figure 4.2a). The concentrations observed in Laxmipur are considerably higher than the W.H.O. recommended limit of $25 \mathrm{mg} / \mathrm{L}$. This in average constitutes around $15.7 \pm 22.1 \%$ of the recommended maximum daily dietary intake of sodium recommended by the American Heart Association of $1500 \mathrm{mg} / \mathrm{d}$ from drinking and cooking water (U.S. Environmental Protection Agency, 2003; American Water Works Association, 1999) (refer to Figure 4.10) In fact, for Laxmipur the potential dietary intake of sodium from drinking and cooking water is much higher than the normally the dietary intake of sodium from water. As stated earlier AWWA reports that normally the dietary intake of sodium from fresh water is around 3 to $5 \%$ (U.S. Environmental Protection Agency, 2003).

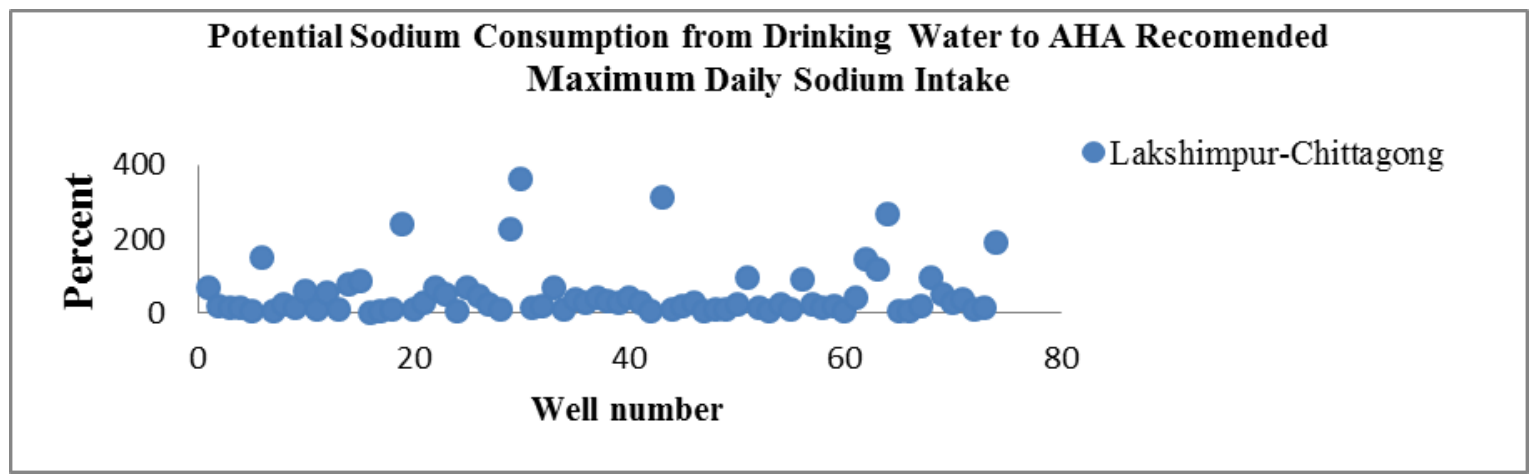

Fig 4.10: Graph of potential daily consumption of sodium from drinking water expressed as a percentage of the

recommended maximum upper limit of daily sodium consumption of $1500 \mathrm{mg} /$ day for Laxmipur In tube well samples of Patiya Upazilla which is only $16 \mathrm{~km}$ (approx.) far from the coast had much higher concentration of sodium. The sodium concentration was found in summer season varying from $61.83 \mathrm{mg} / \mathrm{L}$ to $112.3 \mathrm{mg} / \mathrm{L}$ whose average is $100 \mathrm{mg} / \mathrm{L}$ and median is $112.2 \mathrm{mg} / \mathrm{L}$. This is five times higher than the W.H.O. recommended limit of $25 \mathrm{mg} / \mathrm{L}$ for drinking water. (refer to Table 4.1 and Figure $4.11 \mathrm{a}$ ). During monsoon the sodium concentration was found varying from $22.9 \mathrm{mg} / \mathrm{L}$ to $48.09 \mathrm{mg} / \mathrm{L}$ whose average is $35 \mathrm{mg} / \mathrm{L}$ and median is $35.495 \mathrm{mg} / \mathrm{L}$ which is still higher than the recommended value(refer to Figure $4.11 \mathrm{~b}$ ). It is logical to assume that the area around Patiya upazila may have the same scenario of higher sodium concentration in tube well water. This is putting the mass people of Patiya Upazilla and the surrounding zone in risk of cardiovascular diseases and also in risk of developing hypertension, which can be further investigated by public health organization or similar agencies. 
(a)

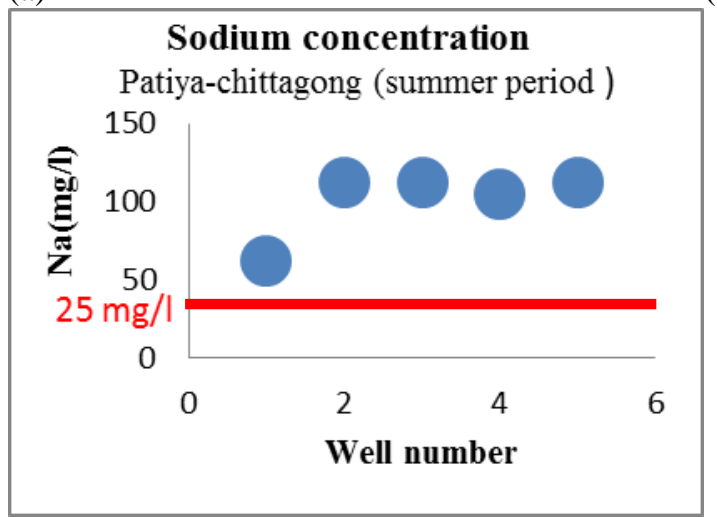

(b)

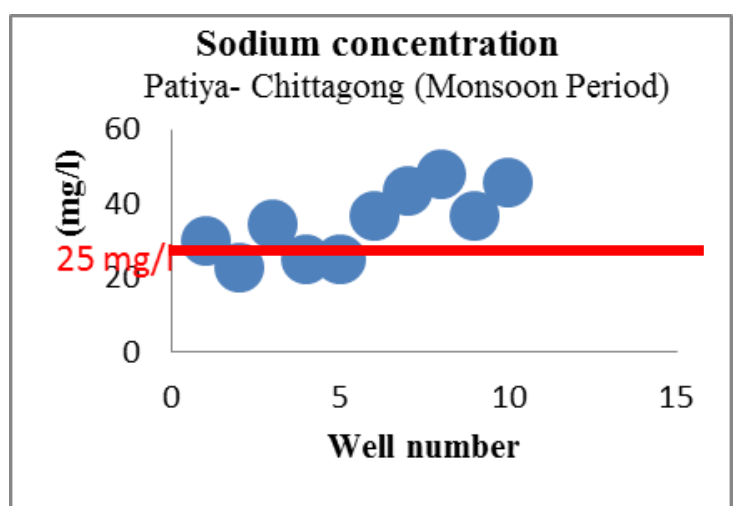

Figure 4.11: Graph of Sodium concentration in Tube well water of Patiya Upazilla showing relation with W.H.O. recommended limit of $25 \mathrm{mg} / \mathrm{L}$ for drinking water (a) Summer Season and (b) Monsoon.

\section{Summary Of Findings}

Since our four sites were at different distances from sea, it was evidently clear that salt water intrusion through the ground water flow is higher in coastal region and it proportionally decreases with distance from the coast.

Deliberate study of the Tubewell sampling of Patiya and Lakshmipur at varying depth found that salt intrusion increases with the increase in depth. In Patiya, all tube wells were deep tube wells since the potable aquifer is found below $600 \mathrm{ft}$. These phenomena confirms the salt water intrusion is higher through deeper aquifer in Patya. We assessed that the reason may lie in the lowering of water table by execesssive withdrawl of well water by pumping, reduction of recharging the potable water aquifer and ground water flow towards sea by the decrese in contributing stream. Also this findings rather explains that with the sea level rise due to global warming, the hydraulic pressure gradient between seawater level and ground water table increases. Thereby, the rate of salinity intrusion in the coastal region is incraesing proportionaly with the sea level rise.

Our deliberate sampling and study in Patiya upazilla based on seasonal variation for both pond and tube well clearly indicates that the salt concentration is higher during summer season and consideraby lower in monsoon. We assessed that due to ground water recharge from both deep percolation and increase in contributing stream flow from Karnafully river in Chittagong district, the salinity intrusion is lowered in monsoon.

Our Analysis of the BGS database of sodium in well water shows that for the inland district Nawabganj and Faridpur, the sodium concentration within the W.H.O. recommended limit of $25 \mathrm{mg} / \mathrm{L}$. American Water Works Association (AWWA) reports that normally the dietary intake of sodium from fresh water is limited to 3 to 5\% (U.S. Environmental Protection Agency, 2003; American Water Works Association, 1999), and the potential sodium daily intake from the waters of Nawabganj and Faridpur were found in line to that reported by AWWA. On the contrary, the sodium concentrations observed in Laxmipur district, which is near the sea are considerably higher than the W.H.O. recommended limit. In fact, for Laxmipur the potential dietary intake of sodium from drinking and cooking water is much higher than the normal safe limit for the dietary intake of sodium from water as stated earlier AWWA reports. Our sampling study and analysis of tube wells and ponds in Patiya Upazilla which is nearer to coast had much higher concentration of sodium than the W.H.O. recommended limit. This is putting the mass people of Patiya Upazilla and the surrounding zone in risk of cardiovascular diseases and also in risk of developing hypertension.

\section{Conclusion}

The study gives an overview of the sodium content in potable drinking water from tube well due to salinity intrusion and its relation with distance from sea, varying depth of aquifer, seasonal variation and daily dietary intake safe limit. We can conclude from the study reported in this paper that the tube wells and ponds in Patiya and Laxmipur has higher sodium concentration than the W.H.O. recommended safe limit contributing to a higher daily dietary intake of sodium. In a larger level, in the tube wells of other coastal localities of Bangladesh are also posing a long term health risk like Patiya and Laxmipur. For this, more studies needs to be done, health advisories should given by the public health authorities and remedial measures should be taken.

The overall concept of our thesis study was based on finding the sodium content in coastal region of Bangladesh due to salinity intrusion, its effects and health risk. The public health and engineering implication of our observation for Patiya as well as Laxmipur is that the higher contribution of sodium from drinking and cooking water poses a long term health risk for the population of developing hypertension and with it 
developing health complications associated with hypertension. We could assess and assume some reasons of salinity intrusion in broader aspects only. Based on the results and findings, some recommendations are listed below:

1. Public health personnel particularly the Department of Public Health Engineering (DPHE), Bangladesh may conduct a public awareness campaign warning the population in the coastal regions in Bangladesh about the high sodium content in their drinking and cooking water. They may also advise the population in the coastal areas to test for salt content in their well waters and reduce their daily dietary salt intake in general.

2. Media publicity can be carried out by Government agencies and NGOs to raise awareness on effects of excessive sodium intake and its long term health risk.

3. Further research on this topic based on the effect of different climatic and non- climatic variables on salt water intrusion can be carried out.

4. Conduct analysis using climate and geo-morphology sensitive model that include temperature, soil strata, sea level rise permeability of soil of the locations, ground water flow rate, ground water table height variations, hydraulic gradient of pressure between sea level to sampling location water table, soil particle size, and electrolytic characteristics of soil grain, etc.

5. A more accurate assessment could be done by collecting data in all season or every month. These would give clear indication in the gradual change pattern in the salt content with respect to seasonal change.

6. Conduct further study on effects of human intervention factors and natural calamities on increase of sodium content in ground water (i.e., lowering by extensive use of tube well water, contamination of both surface and surface water by using fertilizer, pesticides, washing, bathing, chemical waste discharge, tsunami and surges causing flood by sea water, etc.).

Besides some actions are recommended for lowering the sodium content in potable drinking water due to salinity intrusion in coastal region which are given below:

1. Reduce global warming effect by forestation especially in coastal belt.

2. Increase ground water recharge rate in coastal area.

3. Reduce the lowering of ground water table by excessive pumping of ground water particularly in coastal urban areas.

4. Increase the downstream river flow especially in the trans-boundary Rivers by solving bilateral issues.

\section{References}

[1]. O’Donnell, Martin J. et al. "Urinary Sodium and Potassium Excretion and Risk of Cardiovascular Events." Journal of the American Medical Association. Volume 306, Number 20, November 2011.

[2]. Rashid, Shirya and Gordon A. Francis. "Statins and Primary Prevention: Is all the Evidence In?"Canadian Journal of Cardiology. Volume 24, Number 4, April 2008

[3]. Kumanyika, S.K. et al. "Sodium Reduction for Hypertension Prevention in Overweight Adults: Further Results from the Trials of Hypertension Prevention Phase II.” Journal of Human Hypertension. Volume19, Number 1, January 2005.

[4]. Sacks, Frank M. et al. "Effects on Blood Pressure of Reduced Dietary Sodium and the DietaryApproaches to Stop Hypertension (DASH) Diet.” DASH Sodium Collaborative Research Group. New England Journal of Medicine. Volume 344, Number 1, January 2001.

[5]. Water Quality and Treatment: A Handbook of Community Water Supply. Fifth Edition. American Water Works Association. 1999. ISBN 0070016593.

[6]. British Geological Survey, Arsenic Contamination of Groundwater. Volume 4 Data Compilation. BGS Technical Report WC/00/19 Volume 4. ISBN 085272 3849. February 2001.

[7]. EPA 822-R-03-006. Drinking Water Advisory: Consumer Acceptability Advice and Health Effects Analysis on Sodium. U.S. Environmental Protection Agency Office of Water (4304T) Health and Ecological Criteria Division Washington, DC 20460 www.epa.gov/safewater/ccl/pdf/sodium.pdf. February, 2003.

[8]. Hubert, H.B. et al. "Obesity as an Independent Risk Factor for Cardiovascular Disease: a 26-year Follow-up of Participants in the Framingham Heart Study.” Circulation. Volume 67, Number 5, May 1983.

[9]. Shields, Margot, Margaret D. Carroll, and Cynthia L. Ogden. "Adult Obesity Prevalence in Canada and the United States." NCHS Data Brief No. 56, Hyattsville, MD: National Center for Health Statistics Advances in Nutrition. Volume 2, Number 4, July 2011

[10]. Strazzullo, Pasquale et al. "Salt Intake, Stroke, and Cardiovascular Disease." British Medical Journal. Volume 339, November, 2009.

[11]. Atwater, Richard. 2008. Salinity Management Issues Facing Southern California

[12]. Southwest Hydrology. March/April 2008: 16-17.

[13]. Barlow, Paul M. 2003. Groundwater in Freshwater-Saltwater Environments of the Atlantic Coast. U.S. Geological Survey Circular: 1262.

[14]. De Breuck, W. 1991. Hydrogeology of Salt-Water Intrusion: Methods and Instruments.

[15]. Manrique C, Lastra G, Gardner M, Sowers JR. The renin angiotensin aldosterone system in hypertension: roles of insulin resistance and oxidative stress. Med Clin North Am. 2009 May;93:569- 582

[16]. Sarwar, Md. Golam Mahabub. et al. "Impacts of Sea Level Rise on the Coastal Zone of Bangladesh" Lund University, Sweden, 21 November 2005 . 